\title{
Genetic Characterization of Avian Influenza Virus Isolated from Infected Commercial Duck in Sidenreng Rappang, South Sulawesi in 2016
}

\author{
$\underline{\text { Ahmad Nadif }}^{1,2, a)^{*}}$, Fachriyan H. Pasaribu ${ }^{3)}$, Okti Nadia Poetri ${ }^{3, b)}$, Retno D. Soejoedono ${ }^{3)}$, \\ Dwi Desmiyeni Putri ${ }^{4)}$ \\ ${ }^{1}$ Graduate School of IPB, Bogor Agricultural University \\ ${ }^{2}$ Agricultural Quarantine Agency, Ministry of Agriculture Republic of Indonesia \\ ${ }^{3}$ Department of Animal Disease \& Veterinary Public Health, \\ Faculty of Veterinary Medicine, Bogor Agricultural University \\ ${ }^{4}$ Departement of Animal Husbandry, Faculty of Animal Husbandry, State Polytechnic of \\ Lampung \\ ${ }^{a)}$ Corresponding author : ahmadnadif1981@gmail.com \\ b) diapoetri@gmail.com
}

\begin{abstract}
Before outbreaks of avian influenza (AI) among commercial laying duck in Central Java in 2012, duck were considered as reservoir of this virus, the outbreaks reveals that duck were also susceptible for AI infection. The outbreaks among laying ducks in 2012 were caused by AIV subtype H5N1 clade 2.3.2, which is an introduction of new clade of AIV in Indonesia. After the first outbreak, new clade 2.3.2 were spread all over the country, and not only infected duck but also commercial chickens. Sidenreng Rappang is a district at South Sulawesi which have many laying duck farms. On 2016, there is AI outbreaks at most of the duck farms. Our study aim to characterize AIV isolated from outbreaks among laying duck in Sidenreng Rappang. Twenty five cloacal swab samples were randomly collected from seven commercial laying duck farms in Sidenreng Rappang during AI outbreaks on 2016. Samples from each farm were pooled into one sample pool, so that eventually there were seven samples pool. Samples were isolated on specific antibody negative (SAN) embryonated chicken eggs, then followed by identification of AIV subtype $\mathrm{H} 5$ and $\mathrm{N} 1$ using reverse transcriptase-polymerase chain reaction (RT-PCR).Then the PCR product were sequence for HA gene using primer H5-1: 5'-GCC ATT CCA CAT ACA CCC-3' and H5-3: 5'-CTC CCC TGC TCA TTG CTA-3' to determine pathogenicity and clade of these viruses. RT-PCR result showed that all seven isolates were AIV subtype H5N1. Sequencing result of HA gene at cleavage site of all isolates showed pattern "P-Q-R-E-R-R-R-K-R-G-LF",Based on sequencing result, all AIV isolates were belong to high pathogenic AIV clade 2.3.2. In summary, our result showed that high pathogenic AIV clade 2.3.2 were already circulating in Sidenreng Rappang, indicating the necessity of AIV control programme among laying ducks in South Sulawesi.
\end{abstract}

Keywords: laying duck, Sidenreng Rappang, avian influenza virus (AIV), clade 2.3.2

\section{INTRODUCTION}

Avian influenza (AI) is a highly contagious disease caused by influenza A virus, a member of the Orthomyxoviridaefamily (Alexander and Brown 2009), this virus were able to infect 
several bird species, but wild water fowl are considered to be a reservoir. The virus is characterized by surface glycoproteins, of which seventeen hemagglutinin (HA1-HA17) and ten neuraminidase (NA1-NA10) subtypes are distinguished (Yee et al. 2009, Tong et al. 2012). A huge epidemic of high pathogenic (HP) AI virus subtype H5N1 started in Asia in 1996 (Xu et al. 1999). These outbreaks were controlled by stamping-out infected poultry. However, in 2002, the infection re-emerged, followed by spread of the AI virus to other Asian countries like China, Indonesia, Japan, Lao, South Korea, Thailand, Vietnam, and Cambodia, in 2003 and 2004 (Sims et al. 2003; Yee et al 2009), and also spread across the continent to some European and African countries (Alexander and Brown 2009; WHO 2006). First outbreak of AI in Indonesia were happen on 2003, until now Indonesia still an endemic countries of AI.

Waterfowl including ducks were considered as reservoir of AI virus, however, in 2012 there are outbreaks of AI virus among commercial laying duck in Central Java, the outbreaks reveals that duck were also susceptible for AI infection. The outbreaks among laying ducks in 2012 were caused by AIV subtype H5N1 clade 2.3.2, which is an introduction of new clade of AIV in Indonesia. After the first outbreak, new clade 2.3.2 were spread all over the country, and not only infected duck but also commercial chickens. SidenrengRappang (Sidrap) is a district at South Sulawesi, Indonesia which is have many laying duck farms. On 2016, there is AI outbreaks at most of the duck farms. It is confirmed by Center of Veterinary Maros, that the death were caused by AI infection. Information on genetic characterization of AI virus circulating among poultry in East of Indonesia were still limited. Therefore we aim to analyse genetic characterization of AI virus isolated from infected laying duck in Sidenreng Rappang, South Sulawesi, Indonesia.

\section{MATERIAL AND METHOD}

\section{Samples}

Twenty five cloacal swab samples were taken from seven backyards laying duck farms during AI outbreaks in Sidrap in 2016. The swabs were kept in viral medium transport containing PBS-Glycerol-Antibiotics, which was subsequently stored at $-20^{\circ} \mathrm{C}$ until further testing. Samples form each farm were pooled into one sample pool, so that eventually there were seven isolates as follows : Dk/Sidrap/(S1)/2016 referred as S1, Dk/Sidrap/(S2)/2016 referred as S2, Dk/Sidrap/(S3)/2016 referred as S3, Dk/Sidrap/(S4)/2016 referred as S5, Dk/Sidrap/(10)/2016 referred as 10, and Dk/Sidrap/(13)/2016 referred as 13.

\section{Virus Isolation}

Virus isolation were conducted to determine the presence of AIV in swab samples using standard procedure (OIE 2015). Each swab samples were propagated in three embryonated SPF chicken eggs (9 old day), each egg were inoculated with $0.2 \mathrm{ml}$ swab medium, after 60 hours (h), or when the embryo died before that time, the allantoic fluid was harvested. Allantoic fluid were tested using hemagglutination assay (HA) following standard procedure (OIE 2015). 


\section{RNA Extraction}

RNA extraction were done using QiagenRNAeasy TM Total RNA Isolation Kit (Qiagen, Germany) using the manufacturer instructions. A total of $140 \mu \mathrm{L}$ of sample was mixed with $560 \mu \mathrm{L}$ of buffer AVL (containing carrier RNA) into a $1.5 \mu 1$ microtube and mixed until homogeneous before incubated for 10 minutes in room temperature. Afterwards the solution was centrifuged at a speed of $6000 \mathrm{~g}$ for 1 minute and then added ethanol (96-100\%) of 560 $\mu \mathrm{L}$ and then mixed until homogeneous and then re-centrifuged at $6000 \mathrm{~g}$ for 1 minute. A total of $630 \mu \mathrm{L}$ of sample + buffer + ethanol inserted into QIAamp spin column (in the collection tube $2 \mathrm{ml}$ ), then centrifuged at a speed of $6000 \mathrm{~g}$ for 1 minute. The rest of the mixture of sample, buffer and ethanol at microtube re-incorporated into QIAamp spin column (in the collection tube $2 \mathrm{ml}$ ), then centrifuged at a speed of $6000 \mathrm{~g}$ for 1 minute. Later in the QIAamp spin column buffer AW1 added $500 \mu \mathrm{L}$, and then centrifuged for 1 minute at a speed of $6000 \mathrm{~g}$. After QIAamp spin column was transferred to a collection tube was added $500 \mu \mathrm{L}$ of buffer AW2 and centrifuged at a speed of $20000 \mathrm{~g}$ for 3 minutes. After QIAamp spin column was transferred to a $1.5 \mathrm{ml}$ microtube, add $60 \mu \mathrm{L}$ of AVE buffer, and then incubated at room temperature for $1 \mathrm{~min}$ and centrifuged at a speed of $6000 \mathrm{~g}$ for 1 minute. RNA samples were stored at a temperature of $-20^{\circ} \mathrm{C}$ until further used.

\section{RT-PCR of $\mathrm{H5}$}

Identification of $\mathrm{H} 5$ was performed using primer $\mathrm{H} 5-1$ 5'GCCATTCCACAACATACACCC-3' and H5-35'-CTCCCCTGCTCATTGCTA-3' (WHO 2005 ) with PCR product of 219 bp. Composition of the solution to produce PCR products to be used in sorting oligonucleotide consisting of $5 \mu \mathrm{L}$ of $5 \times$ QiagenOneStep RT-PCR Buffer, $1 \mu \mathrm{L}$ dNTP Mix $10 \mathrm{mM}, 1 \mu \mathrm{L}$ of forward primer $0.6 \mu \mathrm{M}, 1 \mu \mathrm{L}$ of reverse primer $0.6 \mu \mathrm{M}, 1$ $\mu \mathrm{L}$ of QiagenOneStep RT-PCR Enzyme Mix, $1 \mu \mathrm{L}$ of RNA $1-2 \mu \mathrm{g}$, and $15 \mu \mathrm{L}$ of RNase-free water so that the total volume to $25 \mu \mathrm{L}$ PCR solution. The solution PCR placed on the PCR machine with temperature setting for reverse transcription was $45^{\circ} \mathrm{C}$ for 60 minutes, predenaturation $95^{\circ} \mathrm{C}$ for 5 minutes, denaturation $95^{\circ} \mathrm{C}$ for 30 seconds, annealing $55^{\circ} \mathrm{C}$ for 30 seconds, extension $72^{\circ} \mathrm{C}$ for 40 seconds with PCR cycle 35 times, and a final extension of $72^{\circ} \mathrm{C}$ for 10 minutes. PCR product visualizations were conducted using

\section{RT-PCR of N1}

Identification of N1 were performed using forward primer N1-1 5'-TTG CTT GGT CGG CAA GTG-3'. and reverse primer N1-2 5'-CCA GTC CAC CCA TTT GGA TCC-3 (WHO 2007 ) with PCR product of $616 \mathrm{bp}$. The composition of the PCR solution consisting of $5 \times 5$ $\mu \mathrm{L}$ QiagenOneStep RT-PCR Buffer, $1 \mu \mathrm{L}$ of $10 \mathrm{mM}$ dNTP Mix, $1 \mu 110 \mu \mathrm{M}$ forward primer, $1 \mu 10 \mu \mathrm{M}$ reverse primer, $1 \mu \mathrm{L}$ of QiagenOneStep RT-PCR Enzyme Mix, $3 \mu \mathrm{L}$ RNA 1- 2 $\mathrm{mg}$, and $13 \mu \mathrm{L}$ of RNase-free water so that the total volume to $25 \mu \mathrm{L}$ PCR solution. The solution PCR placed on the PCR machine with temperature setting for reverse transcription was $45^{\circ} \mathrm{C}$ for 60 minutes, pre-denaturation $95^{\circ} \mathrm{C}$ for 5 minutes, denaturation $95^{\circ} \mathrm{C}$ for 30 seconds, annealing $58^{\circ} \mathrm{C}$ for 30 seconds, extension $72^{\circ} \mathrm{C}$ for 40 seconds with PCR cycle 35 times, and a final extension of $72^{\circ} \mathrm{C}$ for 10 minutes. 


\section{Electrophoresis}

PCR products were separated in $1.5 \%$ agarose gel in TAE buffer stained with ethidium bromide, compared with molecular mass marker and visualized by ultraviolet (UV) transillumination.

Genetic characterization. Nucleotide sequencing of HA gene cleavage site were done by First Base Company (Malaysia) with primerH5-1 5'-GCCATTCCACAACATACACCC-3' and H5-3 5'-CTCCCCTGCTCATTGCTA-3' (WHO 2005). The obtained sequence was edited using BioEdit Sequence Alignment Editor Version 7.0.9.0. Alignment of the sequences was done in MEGA version 6.

\section{RESULT}

RT-PCR of H5 and N1. All seven isolates were able to amplified using H5 and N1 primer indicating that AIV isolated from laying duck in Sidenreng Rappang were belong to H5N1 subtype. Visualizations of RT-PCR product of H5 were presented in fig. 1(a), whilst visualization of RT-PCR product of N1 were presented in fig 1(b).

Nuclotide sequence of HA gene cleavage site. Sequencing result of HA gene at cleavage site of all isolates showed pattern "P-Q-R-E-R-R-R-K-R/G-L-F",Based on sequencing result, all AIV isolates were belong to high pathogenic AIV clade 2.3.2. Overview of RT-PCR result, and nucleotide sequencing result were presented in Table 1.

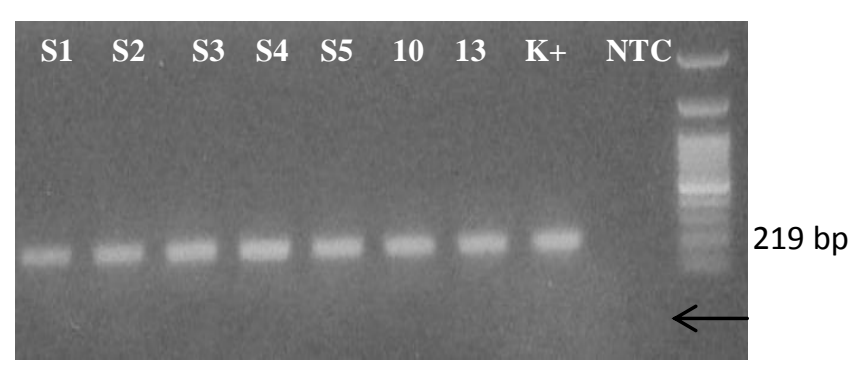

(a)

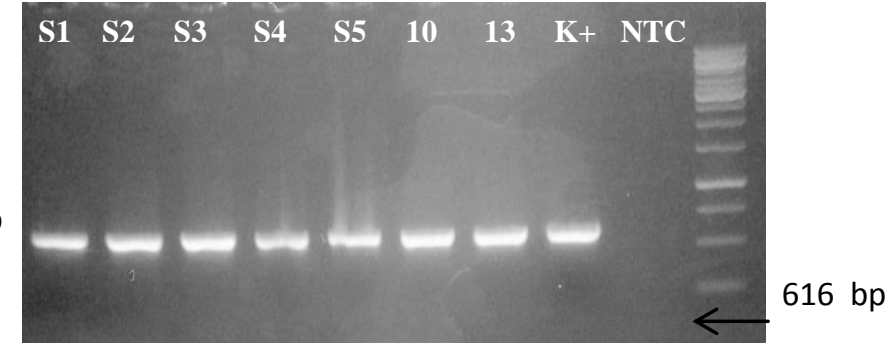

(b)

FIGURE1 (a). H5 amplification results. AIV Isolates: S1, S2, S3, S4, S5, 10,13; K+ is positive control for H5; NTC: non-template ;M: Marker 100 bp. Target PCR product is $219 \mathrm{bp}$; (b)N1 amplification results. AIV Isolates: S1, S2, S3, S4, S5, 10,13; K+ is positive control for N1;NTC: non-template ; M: Marker $100 \mathrm{bp}$. Target PCR product is $616 \mathrm{bp}$. 
Table 1. Overview of RT-PCR result and cleavage site sequence

\begin{tabular}{|c|c|c|c|c|c|c|}
\hline \multirow{2}{*}{$\begin{array}{l}\text { Isolate } \\
\text { number }\end{array}$} & \multirow[t]{2}{*}{ Isolate Name } & \multicolumn{2}{|c|}{$\begin{array}{l}\text { RT- } \\
\text { PCR }\end{array}$} & \multirow{2}{*}{$\begin{array}{c}\text { Sequence Cleavage } \\
\text { Site }\end{array}$} & \multirow[t]{2}{*}{ Pathogenecity } & \multirow[t]{2}{*}{ Clade } \\
\hline & & H5 & N1 & & & \\
\hline S1 & Dk/Sidrap/S1)/2016 & + & + & PQRERRRKRGLF & $\begin{array}{c}\text { High } \\
\text { pathogenic }\end{array}$ & 2.3 .2 \\
\hline S2 & Dk/Sidrap(S2)/2016 & + & + & PQRERRRKRGLF & $\begin{array}{c}\text { High } \\
\text { pathogenic }\end{array}$ & 2.3 .2 \\
\hline S3 & Dk/Sidrap $(\mathrm{S} 3) / 2016$ & + & + & PQRERRRKRGLF & $\begin{array}{c}\text { High } \\
\text { pathogenic }\end{array}$ & 2.3 .2 \\
\hline S4 & Dk/Sidrap $(\mathrm{S} 4) / 2016$ & + & + & PQRERRRKRGLF & $\begin{array}{c}\text { High } \\
\text { pathogenic }\end{array}$ & 2.3 .2 \\
\hline S5 & Dk/Sidrap(S5)/2016 & + & + & PQRERRRKRGLF & $\begin{array}{c}\text { High } \\
\text { pathogenic }\end{array}$ & 2.3 .2 \\
\hline 10 & Dk/Sidrap(10)/2016 & + & + & PQRERRRKRGLF & $\begin{array}{c}\text { High } \\
\text { pathogenic }\end{array}$ & 2.3 .2 \\
\hline 13 & Dk/Sidrap(13)/2016 & + & + & PQRERRRKRGLF & $\begin{array}{c}\text { High } \\
\text { pathogenic }\end{array}$ & 2.3 .2 \\
\hline
\end{tabular}

\section{DISCUSSION}

First AIV outbreaks in Indonesia were first detected in commercial layer flocks in Banten province, West Java in 2003, and subsequently spread to other parts of the country. AIV outbreaks caused huge economic losses to the poultry industry and since 2003 Indonesia has become endemically infected (Domenech et al. 2009). In January 2004, HPAI H5N1 outbreaks were officially announced in 11 provinces, causing the death of approximately 20 million birds (Naipospos 2005; Sedyaningsih et al. 2007). Since then, surveillance were included as one of nine point strategy on eradicating AIV in Indonesia. From January 2006, Indonesian government initiated the participatory disease surveillance and response (PDSR) programme in an attempt to control HPAI in sector-4 across Bali, Java, and parts of Sumatra (Azhar et al. 2010; Loth et al. 2011). Indonesian government, since 2007, with the assistance of the United Nations Food and Agriculture Organization (FAO)-joint network of expertise Avian influenza (OFFLU) established molecular surveillance system for HPAI called the Influenza Virus Monitoring (IVM) network (Hartaningsing et al. 2015).

Previous study has been done to analysescharacter of circulating AIV in Indonesia, Lam et al. (2012) has been studied phylodinamics of AIV H5N1 in Indonesia, and Wibawa et al. (2012) has been studiedmolecular survey of AIV H5N1 isolated from duck in Central Java Indonesia. Pre dominant AIV H5N1 circulating in Indonesia from 2005 up to 2012 were belong to clade 2.1.3 (2.1.3.1, 2.1.3.2, 2.1.3.3). Then, there is new introduction of AIV H5N1 clade 2.3.2 which caused AIV outbreaks among laying duck in Central Java on 2012 (Wibawa et al. 2012). Therefore, it is importance to do continuous surveillance of AIV in order to understand the evolution and genetic character of the AI circulating virus. 
Based on RT-PCR H5 and N1 result, also nucleotide sequencing of amino-acids at cleavage site, all AIV isolates in our study were belong to high pathogenic AIV subtype H5N1 clade 2.3.2. Pathogenecity of AIV can be determined based on the intra-venous pathogenicity index (IVPI) of $>1.2$ were HPAI, or based on the sequence of amino-acids at the cleavage site (OIE. 2015). In the current study, we determined the pathogenecity using nucleotide sequencing of amino-acids at cleavage site. Repetition of arginine or lysine at amino-acid sequence at cleavage site were classified as high pathogenic AIV. Nucleotide sequence of amino-acid at cleavage site of all isolates showed motif P-Q-R-E-R-R-R-K-R/GL-F.According OFFLU (2014) AI virus has the amino acid pattern P-Q-R-E-R-R-R-K-R/GL-F classified as HPAI H5N1 and belong to the clade 2.3.2. Our conclusion would be that the AI virus circulating among laying duck in Sidenreng Rappang were high pathogenic AIV subtype H5N1 clade 2.3.2. Our result, indicating the necessity of AIV control programme among laying ducks in South Sulawesi.

\section{REFERENCES}

1. M. Azhar, A.S. Lubis, E.S. Siregar, R.G. Alders, E. Brum, J. McGrane, I. Morgan, P. Roeder, Participatory disease surveillance and response in Indonesia: strengthening veterinary services and empowering communities to prevent and control highly pathogenic avian influenza.Avian Dis, 54:749-753. (2010).

2. D.J. Alexander and I.H. Brown. History of highly pathogenic avian influenza. Rev Sci Tech Off Int Epiz, 28:19-38. (2009).

3. J. Domenech, G. Dauphin, J. Ruston, J. McGrane, J. Lubroth, A. Tripodi, J. Gilbert, L.D. Sims, Experinces with vaccination in country endemically infected with highly pathogenic avian influenza: the Food and Agricultural Organization perspective, Rev Sci Tech Off Int Epiz, 28:293-305 (2009) .

4. N. Hartaningsih, H. Wibawa, Pudjiatmoko, F.S.T. Rasa, S.H. Irianingsih, R. Dharmawan, M. Azhar, E.S. Siregar, J. McGrane, F. Wong, P. Selleck, J. Allen, I. Broz, M.K. Torchetti, G. Dauphin, F. Claes, W. Sastraningrat, P.A Durr, Surveillance at the molecular level: developing an integrated network for detecting in avian influenza viruses in Indonesia, 2015.

5. L. Loth, G. Marius, W. Jianmei, C. Christina, H. Muhammad, Prev Vet Med, 102:50-58 (2011).

6. T.S.P. Naipospos, Current situation with highly pathogenic avian influenza (HPAI) in Indonesia with special emphasis on control at village level, Presented at International Conference-AusAID Southern Africa Newcastle Disease Control Project, Dar es Salaam Tanzania (5-7 October 2005).

7. [OIE\}Office International des Epizootica, Avian influenza: Infection with avian influenza

virus, http://www.oie.int/fileadmin/Home/eng/Health_standards/tahm/2008/pdf/2.03.04_AI.pdf , 2015 [Accessed 23 February 2017].

8. OFFLU OIE/FAO Network of Expertise on Avian Influenza. Influenza A cleavage site, 2014.

9. E.R. Sedyaningsih, S.Isfandari, V. Setiawaty, L. Rifati, S. Harun, W. Purba, S. Imari, S. Giriputra, P.J. Blair, S.D. Putnam, T.M. Uyeki, Soendoro, Epidemiology of cases of 
H5N1 virus infection in Indonesia July 2005-June 2006 J Infect Dis, 196:522-527 (2007).

10. L.D. Sims, T.M. Ellis, K.K. Liu, K. Dyrting, H. Wong, M. Peiris, Y. Guan, K.F. Shortridge, Avian influenza in Hongkong 1997-2002, Avian Dis, 47:832-838 (2003)

11. S. Tong, Y. Li, P. Rivailler, C. Conrady, D.A.A. Castillo, L.M. Chen, S. Recuanco, J.A. Ellison, C.T. Davis, I.A. York, A.S. Turnelle, D. Moran, S. Rogers, M. Shi, Y. Tao, M.R. Weil, K. Tang, L.A. Rowe, S. Sammons, X. Xu, M. Frace, K.A. Lindblade, N.J. Cox, L.J. Anderson, C.E. Rupprecht, R.O. Donis, A distinct lineage of influenza A virus from bats (Proc Natl Acad Sci, USA, 2012), 109:4269-4274.

12. H. Wibawa, W.B. Prijono, N.L.P.I. Dharmayanti, S.H. Irianingsih, Y. Miswati, A. Rohmah, E. Andesyha, R.S.D. Daulay, K. Safitri, Investigasi wabah penyakit pada itik di Jawa Tengah, Yogyakarta, dan Jawa Timur: identifikasi sebuah clade baru virus avian influena subtype H5N1 di Indonesia (Buletin Laboratorium Veteriner, Indonesia, 2012)pp12: 2-9

13. [WHO] World Health Organization, Recommendations and laboratory procedures for detection of avian influenza $\mathrm{A}(\mathrm{H} 5 \mathrm{~N} 1)$ virus in specimens from suspected human cases, 2007.

14. [WHO] World Health Organization, Successful strategies in controlling avian influenza, 2006.

15. [WHO] World Health Organization Recommendations and laboratory procedures for detection of avian influenza $\mathrm{A}(\mathrm{H} 5 \mathrm{~N} 1)$ virus in specimens from suspected human cases, 2005.

16. X. Xu, K. Sobbarao, N.J Cox, Y. Guo, Geneticcharacterization of the pathogenic influenza A/Goose/Guangdong/1/96(H5N1) virus: similarity of its hemagglutinin gone to those of H5N1 viruses from 1997 outbreaks in Hongkong, Virology, 261:15-19 (1999).

17. T.T.Y. Lam, C.C. Hon, P. Lemey, G. Oliver, Pybus, M. Shi, H.M. Tun, J. Li, J. Jiang, C. Edward, Holmess, F.C.C. Leung, Phylodynamics of H5N1 avian influenza virus in Indonesia, Molecular Ecology, 21:3062-3077 (2012).

18. K.S. Ye, T.E. Carpenter, C.J. Cardona, Epidemiology of H5N1 avian influenza (Comp Immunol Microbiol Infect Dis, 32:325-340 (2009). 